\title{
Ethnoscapes as Spectacle: Reimaging Multicultural Districts as New Destinations for Leisure and Tourism Consumption
}

\author{
Stephen Shaw, Susan Bagwell and Joanna Karmowska
}

[Paper first received, January 2003; in final form, May 2004]

Summary. Neo-liberalism may intensify competition, not only between, but also within cities, as local authorities collaborate with commercial and third-sector organisations to nurture emerging visitor economies. This article considers reimaging strategies that trade upon features of the place-product that include ethnic cuisine, street markets and festivals, set against the backdrop of an exoticised urban landscape. Through longitudinal case studies of two multicultural districts in east London, the authors examine the public policy rationale for their selection and redefinition as new destinations for leisure and tourism, identifying the key agents of change and the range of techniques used to market ethnic and cultural difference. This leads to a critical discussion of the issues arising for urban governance and the reconciliation of their role as social and commercial hubs for minority groups, with the accommodation of high-spending leisure consumers from the dominant culture and, in some cases, international tourists.

\section{Introduction}

Over the past decade or so, disadvantaged, multicultural districts of cities in the UK and elsewhere in Europe have been selected, developed and marketed as new destinations for leisure and tourism. Gritty and characterful areas, usually on the fringe of city centres, are made accessible, safe and visually appealing to visitors who are considerably more affluent than the local population. Expressions of multiculturalism in the built environment, along with markets, festivals and other events in public spaces, are presented as picturesque back-drops for consumption. Streets and neighbourhoods, whose very names once signified the poverty of marginalised communities, are repositioned to attract people with sophisticated, cosmopoli- tan tastes. An emerging visitor economy can thus provide an essential catalyst: a model of market-led regeneration that draws from theory and practice in North America. Opinion is, however, deeply divided over the appropriateness of marketing such areas to highspending visitors and there is uncertainty as to how the longer-term issues and problems should be addressed. This paper will critically examine the contributions of theorists and practitioners to this debate.

It will consider, in particular, the signifiers of ethnic or cultural difference that have been inscribed into urban landscapes. Not only do these 'texts' communicate meaning between people of a particular minority group; they are also gazed upon by visitors who seek out 
goods and services that they value as exotic. As with tourism in less developed countries, the responses of local entrepreneurs to the varied demands of visitors to multicultural districts may produce dissonant landscapes of multiple realities and contested meanings (Tunbridge and Ashworth, 1996; Aitchison et al., 2002). The following section will investigate the processes through which such places are 're-constructed', both physically and socially. This leads to a critical assessment of the mediating role of urban authorities and regeneration agencies that use themes of ethnic or cultural identity to add value to the 'place-product' in commercial exchange with visitors. Such aestheticisation and promotion of inner-city streets as exotic landscapes of consumption is then discussed with reference to case studies of two multicultural districts in east London, neither of which had seemed likely candidates for leisure and tourism-led regeneration until the 1990s.

\section{Ethnoscapes and the Entrepreneurial City}

\section{Accommodating the Majority Culture}

Landry and Bianchini (1995, p. 28) highlight the special contribution of settled immigrants to the creative as well as economic life of cities: outsiders and insiders at the same time, they have different ways of looking at problems and different priorities. Historically, Jewish entrepreneurs reinvigorated areas of Amsterdam, Antwerp and Vienna, while more recently, their Asian counterparts established thriving evening and weekend economies in UK cities, serving diverse markets while maintaining a separate identity. In cities that are receptors of increasingly volatile cultural flows, people adapt, as well as adapt to their new-found urban environments, constructing what Appadurai (1997, p. 33) terms 'ethnoscapes': landscapes of those who "constitute the shifting world in which we live". Where property rights and planning regulations allow, they may recreate the architecture of former homelands with a marked emphasis on correct design and execution, most notably in their places of worship. Conversely, through 'ethnic' restaurants oriented to Western tastes, they may, in Valene Smith's (1989) terminology, play host to customers from 'host' societies, exploiting familiar if not clichéd images. Far more than a nourishing meal, they may offer total immersion in vicarious travel: "an effortless voyage into some distant enchantments" (Zelinski, 1985, p. 54).

Such fabrication of exotica may expand from the interior world of restaurants into the street. In her seminal study of Vancouver's 'Little Orient', Anderson (1995) uses a 'jeweller's eye view' to expose the workings of a powerful and protean cultural hegemony by European settlers in the New World. From the city's foundation in the 1870 s and for over half a century, Chinatown was mythologised by European migrants as a place of sinful and sinister activities. By the mid 1930s, however, its shops and restaurants were accommodating trade from non-Chinese customers and deliberately accentuating the romance of Old Cathay through lanterns, dragons, pagodas and neon signs. Hitherto, such festive decorations had not been features of the street scene. In European cities, tourism-oriented Chinatowns are now as firmly established as their counterparts in North America. Places associated with other minorities, such as North Africans in French and Belgian cities, have attracted tourists less easily but, as Featherstone (1991, pp. 96-97) observes, some visitors are particularly drawn to 'low life places' as alternatives to more traditional forms of high cultural consumption such as museums and galleries. In West Berlin, after the wall was erected in 1961, the low-rent district of Kreuzberg became home to Gastarbeiter who migrated from Turkey and Yugoslavia to meet shortages of labour, as well as artists and young men from elsewhere in Germany avoiding conscription. By the 1990s, however, the area once associated with foreigners and dissenting radicals had entered mainstream guidebook culture as a 'bohemian quarter' of the new federal capital.

Everyday places and features of multicultural districts may thus be transformed into 
objects of place-consumption, but there is considerable variation in the aesthetic prejudices and predilections of those who gaze upon them. In his influential historical analysis of the East in the European imagination, Said observed that

Americans will not feel quite the same about the Orient, which for them is much more likely to be associated very differently with the Far East (China and Japan, mainly) (Said, 1978, p. 1).

Long after independence, Arabia and IndoChina have particular significance for French imagery of the exotic, Indonesia for the Dutch, India for the British-for, not only were they the domain of 'their' oldest and richest colonies, they defined the very notion of Europe as a contrasting image. In the second half of the 20th century, immigration from former colonies conferred the reality as well as the myths of post-imperialism to some European cities. Henry et al. (2002) describe a globalisation from below that brought imperial frontiers into the heart of Birmingham and other cities in the UK, reactivating discourses of Empire. To Daily Telegraph readers in the early 1980s, young White gentrifiers were 'colonisers', restoring civic pride to inner-city areas (Burgess, 1985), while Asian shops and restaurants could package romantic images of the British Raj in a racialised construct tuned to multicultural consumerism (Jacobs, 1996).

Post-imperial sentiment may thus play a part in the reimaging of some urban landscapes, but there is evidence that the gaze of place-consumers is becoming more diverse, complex and discerning (Aitchison et al., 2002). Some forms of urban tourism have an educative dimension, some a social conscience. Recent studies have-for example, emphasised the discerning tastes of cultural omnivores for whom an appreciation of contemporary ethnic cuisine is regarded as a marker of distinction (Warde, 1995; Taylor, 2000). Far from seeking the reassurance of food adapted to European taste, they pursue 'authentic' food experiences as cultural capital. Rotterdam's 'City Safari' initiative en- courages visitors to make their way on foot, by bicycle or public transport to deprived multicultural districts. Biles (2001) reports that itineraries are arranged to over 250 addresses that include a centre for asylum-seekers, a halal butcher, temples and mosques. The self-guided tours are designed to challenge people's preconceptions of the everyday lives of recent migrants to the Netherlands, and make a modest contribution to the local economy. Although the object of their quest is in the European inner city, the motivation of the participants has much in common with 'ethnic tourists' and their search for the "ethnically exotic in as untouched, pristine, authentic form" as can be found (van den Berghe, 1994; quoted in Hitchcock, 1999, p. 17).

In their discussion of the spatial consequences of 'urban ethnic encounters', Erdentug and Colombijn (2002, pp. 10-11) adapt Barth's (1994) three-level geographical hierarchy to investigate spatial expressions of the boundaries of ethnic difference. With reference to their analytical framework, the main focus of this paper is upon the 'meso level' of multicultural districts and how such areas are delineated on the tourist map. An understanding of the processes through which territorial boundaries are negotiated will also require reference to the 'macro level' of urban governance; for, the public policy framework of city planning, regeneration, place-marketing and other functions may constrain, enable or encourage expressions of ethnic difference in the built environment. Furthermore, the 'bird's eye view' should be counter-balanced and complemented by reference to the 'micro level' of bounded space. It is therefore necessary to consider the fine grain of buildings, streets, squares, parks and market-places, and the ramifications for ethnic minority residents, especially their use (or non-use) of private and public spaces within their immediate neighbourhood. In the context of this paper, the micro level will refer to their interaction with visitors and the economy that services visitor requirements, where ethnic and cultural difference features as a key element of the place-product. 


\section{Trading on Ethnic and Cultural Difference}

The role of migrant communities as prime movers in the regeneration of areas where they have settled has a particular appeal from advocates of neo-liberalism. In his influential article in Harvard Business Review, Michael Porter (1995, p. 57) argues that inner-city authorities seeking to reduce dependence on government aid and welfare payments should capitalise on their strategic advantages. Thus, his locational principles previously outlined in The Competitive Advantage of Nations (Porter, 1990) are "just as relevant to smaller areas such as the inner city". Using illustrations drawn exclusively from North America, he recommends that public intervention should work in harmony with market forces and build upon the true competitive strengths of firms in inner-city areas. These include, in particular, proximity to downtowns, entertainment and tourist attractions, as well as the entrepreneurial talent and low-cost labour to be found within migrant communities. Kotler et al. (1993, p. 78) also use examples from the US to commend a new maturity in place-marketing that emerged in the 1990s, as enlightened city governments eschewed crude civic boosterism in favour of 'strategic image management' and competitive niche thinking. Rather than compete with other places on an undifferentiated 'me too' basis, such cities use strategic foresight to define their sustainable competitive advantage. Within large cities, districts where older industries are in decline can likewise cultivate niche products that create value for target audiences such as tourists and tourism investors.

As illustrated in the case studies below, some inner-city authorities in the UK have adopted versions of this model, exploiting their nearness to city centres and tourist honeypots, as well as the entrepreneurial talent of ethnic minority firms that respond to the growing demand for food, entertainment and other exoticised products. Nevertheless, critics on both sides of the Atlantic construe a darker side of leisure and tourism-led regeneration. Through reimaging of places as land- scapes of consumption, such space 'transactions' may lead to displacement of established low-rent residents and small businesses (Zukin, 1991, 1999). Judd is also critical of Disneyfied 'Latin Quarters' and festivals associated with them, as "islands of pure consumption" for visitors who are wealthier than the local population: "when this is the case, tourist bubbles are more likely to contribute to racial, ethnic and class tensions than to an impulse towards local community" (Judd, 1999, p. 53). The development of urban tourism may lead to deepening alienation of those among the local population who are expected to service the visitors and play the role of resident actors to animate the scene (Shaw and MacLeod, 2000).

As Orbasli (2000) argues, in general local authorities have tended to react to the consequences of leisure and tourism, rather than establish workable objectives for sustainable community-based development to integrate the form and function of streetscapes and public spaces. In Granada, centre of Moorish rule in Spain until the 15th century, a large Muslim population still lives in the picturesque but poor historical district of Albaicin. For its close-knit communities, the area represents "a meaning apparent in neighbourly gatherings on summer evenings" and "lively fiestas" (Orbasli, 2000, p. 34). In 1989, a Conservation Area Plan was formulated for Grenada. However, the plan was unable to attract financial assistance, and heritage interests targeted resources, not on improving living conditions for residents, but on projects with tourism potential, such as preservation of the city walls. Over several decades, the condition of many residential buildings in the Albaicin Quarter had fallen into disrepair, as few of its low-income residents could afford even basic maintenance. Out-migration had relieved overcrowding, but had also led to abandonment and dereliction. From the early 1990s, the Albaicin began to change as wealthy newcomers acquired and converted property into fashionable holiday homes. Although this has enabled historical buildings to be restored in 
conformity with 'traditional styles', the district's social mix has been profoundly transformed. And, through the influx of day visitors from the coastal resorts of Andalucia, its characteristic Islamic identity has been eroded; the routines of its established residents disturbed by visitors attracted to its romantic Otherness.

The inability of municipalities to regulate and guide the sustainable growth of urban tourism is equally apparent in post-communist central and eastern Europe (Ashworth, 1996; Hall, 2002). In Cracow, Poland, the World Heritage site of Kazimierz reflects the respective traditions of the Christian and Jewish communities that cohabited the district from the 14th century (Bogdanowski, 1985). At the beginning of the Second World War, the Jewish population of Cracow had been 63000 (about a quarter of the city's inhabitants), with a high proportion living in Kazimierz, but tragically nearly all became victims of the Nazi genocide (Duda, 1991). During the communist era, the district lost much of its former identity. Although it remained one of the most densely populated districts of Cracow, much of its housing was rented to the city's poorest citizens, the buildings severely neglected by landlords who had little incentive to carry out repairs. With the demise of communism, there was considerable optimism concerning the 'virtues of tourism' and its ability to generate income and wealth in disadvantaged areas (see Paszucha, 1995) and Kazimierz became the subject of a European Union-funded regeneration strategy during 1993/94-2003/04. The Action Plan promised to revitalise this run-down but potentially attractive quarter through a balanced mix of residential, commercial and visitor uses to restore its distinctive cultural duality. In practice, however, hardly any of the strategy's recommendations have been implemented and market forces have displaced many of the former low-rent residents and craft industries (KIN, 2000).

Restoration of built heritage has been highly selective, focusing primarily on flagship sites in the streets now sign-posted to visitors as the 'Old Jewish Quarter'. These include a former 19th century prayerhouse, restored to provide a centre for Jewish culture with substantial finance from the US Congress, as well as from the municipality, province and Polish Ministry of Culture. There are also major festivals that celebrate Jewish traditions and which draw large international audiences. However, the most notable and unexpected agent of change was tourism inspired by cinema, as the area around Szeroka Street featured prominently in Spielberg's (1993) film Schindler's List. The place has thus attained celebrity status; a destination readily included in itineraries of Poland, especially those targeted at tourists from western Europe, Israel and North America. From the mid 1990s, some buildings in this part of Kazimierz found new commercial uses as 'Jewish-style' cafés, restaurants and hotels. Although prominently displaying signs in Hebrew and offering traditional food and musical entertainment, nearly all are managed and staffed by Polish Catholics. The district has also become highly attractive as a residential location for the city's rising middle class of young professionals and business people, with a proliferation of bars, nightclubs, contemporary arts and music venues, its somewhat studied theatricality juxtaposed with memorials to the Holocaust.

\section{Place-consumption and Cultural Identity in Inner London}

\section{Place-marketing and the UK Context}

There are, indeed, some fundamental difficulties with transplanting place-marketing philosophies and techniques from North America, with its long history of interurban and intraurban rivalry to attract settlers, investors and developers (Shaw, 2004). As Ward (1998, p. 234) stresses, post-industrial city marketing is "essentially an American invention", deeply rooted in a political agenda that eschews big government. In most countries in western Europe, as well as those in post-communist central and eastern $\mathrm{Eu}-$ 
rope, the assumption that cities must compete in a 'market' sits uneasily with their more interventionist and hierarchical macro level structures for urban governance (Ashworth and Voogt 1994). Promotion by cities such as Lille, Rotterdam and Liège, and districts within them, take place in a far more co-ordinated, top-down framework, negotiated by cities with regional and national authorities. Municipalities in the UK also operate within a much tighter legal and fiscal system than those in the US, but in the wake of dramatic reductions in grants to local authorities, the Conservative government 1979-97 injected a spirit of urban entrepreneurship that, according to the rhetoric, would replace welfare dependency. Along with heightened competition for inward investment, skilled knowledge workers and tourism, it encouraged urban authorities to compete with one another for government funding to support regeneration programmes.

After the 1987 election and Prime Minister Margaret Thatcher's statement that she would "Do something about those inner cities", Action for Cities (Cabinet Office, 1988) announced the government's intention to reorient urban policy towards "a permanent climate of enterprise in the inner cities, led by industry and commerce" (quoted in Cullingworth, 2002, p. 298). From 1991 under 'City Challenge', the private sector was expected to play a significant role in competitive bidding for regeneration funding designed to encourage strategic thinking. Building on this approach, the Single Regeneration Budget (SRB) promised more flexible funding arrangements for programmes that could demonstrate a close working relationship between local agents of change in the commercial and voluntary sector to deliver the desired outputs. Colenutt and Cutten (1994, p. 239) characterise this partnership approach as a tool that obliges the actors to engage in consensus politics, silencing opposition in order to secure at least some benefits for the area concerned. Potts (2002) comments that in the UK, as in the US, the competitive advantage of 'social cohesion' has been an important catalyst for such col- laboration. For cities nurturing an emerging visitor economy, the need to promote their ability to tackle crime and disorder is paramount. Such places must present positive images of themselves to the outside world. However, in doing so, they may well "underplay the social reality that necessitates renewal and regeneration programmes in the first place" (Williams, 2003, p. 24).

In a policy environment that required collaboration to secure competitive advantage, urban authorities in the UK readily adapted place-marketing models derived from North America. Some developed highly successful strategies for image reconstruction: Glasgow (Paddison, 1993), Birmingham (Lutz and Ryan, 1997) and Manchester (Schofield, 1996; Williams, 2003) being notable examples. Some cultivated a vibrant cosmopolitan image by promoting attractions and events that owed their existence to immigrant communities. Urban entrepreneurship could thus be reconciled with multicultural perspectives of social inclusion hitherto more associated with the Left. Urry (1990, p. 144) describes "cultural reinterpretation of racial difference" in Bradford's guide to the Flavours of Asia that promoted Asian restaurants and sari centres, accompanied by a brief history of Asian religions and immigration to the city. Birmingham's ethnic diversity is also celebrated in its promotion of music, food and drink offered by transnational communities that include Pakistanis, Chinese and AfroCaribbeans (Henry et al., 2002). Fine cuisine and the creative arts are also key attractions in the SRB-funded renaissance of Ancoats 'urban village'. In this case, the chosen theme is intraEuropean migration, interpreted from a heritage perspective, as the original inhabitants of 'Little Italy' have long moved away from this particular district of Manchester (Taylor, 2000).

With the election of the New Labour government in 1997, the SRB funding framework was kept, but the Challenge Fund is now administered through the Regional Development Agencies and is explicitly promoted as an instrument to tackle social exclusion. The overall priority is now to 
improve quality of life for local people in areas of need by reducing the gap between deprived and other areas, and between different groups. Partnerships must therefore demonstrate how local communities were involved in working up the bid, what arrangements were in place to ensure they had a say in decisions and how local community projects will be funded (DETR, 1998). However, as Edwards (2003) points out, the definition of 'community' is problematic. On the one hand, guidance for applications suggests that it is a matter for partnerships to decide who or what the local community might be. On the other hand, communities include the "faith-based voluntary sector ... ethnic minorities and local volunteers" (DETR, 1998, p. 5). Whilst acknowledging the government's willingness to address previous criticism that the Challenge Fund favoured the commercial interests of property-led regeneration, North (2003, p. 121) highlights the somewhat tarnished reputation of a bureaucratic process that "emphasises number crunching rather than 'real' results or innovation" and places a particular burden on small, community-based organisations. A further source of concern is that no guidance was given on the relationship between SRB programmes and land use planning (Cullingworth, 2002). What if the vision of an SRB programme conflicts with a statutory development plan, and the wishes of the local 'community' previously expressed in the public participation required for its adoption?

The development of leisure and tourism consumption as a catalyst for the regeneration of inner urban areas has been the subject of a considerable volume of policy rhetoric. However, the longer-term social effects of interventions to stimulate urban visitor economies are poorly understood. As Maitland (2003, p. 49) concluded in his study of emerging cultural tourism destinations in the London Boroughs of Islington and Southwark, "we do not yet know enough about the processes to be confident that we can plan them thoroughly through public policy". The following section investigates area-based de- velopment and marketing of difference with reference to two emerging 'cultural quarters' in inner London: Brick Lane as 'Banglatown' in Spitalfields, Tower Hamlets and Green Street in West Ham, Newham. Through these case studies, the authors critically examine

1. the public policy rationale for selection and redefinition of multicultural districts as destinations for leisure and tourism consumption;

2. the key agents of change and range of techniques used to develop a visitor economy and to market ethnic and cultural difference; and

3 . the sustainability of regeneration strategies and the issues arising for urban governance.

The authors assess the reimaging of the two areas through longuitudinal case studies from the 'entrepreneurial turn' of urban policy of the late 1980s, heralded by Action for Cities. This leads to a more detailed examination of regeneration programmes relating to the period 1997-2002. The approach includes analysis of 'regeneration discourse' articulated in bid applications, policy statements, monitoring and review documents published by SRB-funded partnerships and interviews with key informants, especially senior mangers of partnership agencies, local authority councillors and officers. This is supplemented by observations of the reorientation of urban landscapes towards a visitor economy and consideration of how these changes have been interpreted through media and guidebook coverage.

\section{Brick Lane as 'Banglatown', Spitalfields, LB Tower Hamlets}

The Rough Guide to London draws attention to images that still associate themselves with London's East End. The influential guidebook for more adventurous travellers describes a place once regarded as 'the hell of poverty'

Its name is synonymous with slums, 
sweatshops and crime, as epitomised by anti-heroes such as Jack the Ripper and the Kray Twins, but also with the rags-toriches careers of the likes of Harold Pinter and Vidal Sassoon, and whole generations of Jews who were born in the most notorious of London's cholera-ridden quarters and have now moved to wealthier pastures ... The East End is constantly changing, as newly arrived immigrants assimilate and move out (Humphreys, 2002, p. 265).

In this place-narrative, Brick Lane, Spitalfields-'high street of the ghetto' in an area that was almost 100 per cent Jewish-is now the heart of the city's Bengali community. During the 1970s, it became the 'front line' of defence against violence orchestrated by the National Front and British National Party. Racist attacks have continued intermittently, but today there is little visible evidence of tension along the main thoroughfare. For the visitor who explores Brick Lane on foot, 'Banglatown' offers a remarkable assault on the senses

The southern half of Brick Lane is the central focus of what is increasingly referred to a 'Banglatown'. Here, brightcoloured sari fabrics line clothes-shop windows, the heavy beat of bhangra music emanates from music shops and passing cars, and the smell of spices wafts from the numerous Bangladeshi cafés and restaurants (Humphreys, 2002, p. 272).

Only a decade ago, however, the very concept of 'Banglatown' stirred deep controversy. In 1989, the would-be developers of high-rise offices on a 27 -acre site straddling Brick Lane-Truman's Brewery (Grand Metropolitan) and Bishopsgate Goodsyard (Railtrack)—were mindful of opposition to redevelopment of Spitalfields Market nearby (see Woodward, 1993). An association of Bengali-owned firms formed as the 'Community Development Group' (CDG) announced that they would not oppose redevelopment of the Brick Lane site, which they regarded as an opportunity to secure "maximum community influence" (CDG, 1989, p. 4). With funding from the Prince of Wales' Business in the Community scheme, CDG produced a 'community plan' and unilaterally opened negotiations with the developers for "community benefits" that included a 12-acre 'Banglatown' shopping centre to serve Bengalis and visitors wanting "ethnic food and crafts" (Fainstein, 2001, pp. 144145). Jacobs (1996, p. 100) highlights the divisiveness of selective engagement of pressure-groups in bargaining for planning gain-for in this case, even within the Bengali population, there was opposition to the development and their Labour representatives on the Council expressed scepticism about the Banglatown idea.

As the property recession of the early 1990s began to bite, the scheme looked less viable, as did CDG's aspirations. Meanwhile, LB Tower Hamlets, with partners that included CDG, successfully bid for a City Challenge grant of $£ 7.2$ million to regenerate the Bethnal Green area, including Spitalfields 1992-97. In 1995, the programme team briefly revived 'Banglatown' to promote Brick Lane in a poster campaign on London Underground and supporting leaflets, but press coverage, especially in the Evening Standard, was less than favourable and the name was dropped again. Under SRB, which replaced City Challenge, a further bid secured $£ 11.4$ million 1997-2002 for regeneration projects to strengthen links with the City and encourage diversification of the local economy, especially leisure and tourism. The vision for what became the 'Cityside' programme would 'pioneer a new model of regeneration'. Its aims (LB Tower Hamlets, 1996, p. 1) were to

1. establish the area as one of the most attractive and accessible business locations in the capital;

2. develop opportunities between the corporate sector and micro and small firms;

3. expand the tourism potential of the area in order to stimulate economic activity, drawing on London's strength as a world city; 
4. encourage greater integration of economic development in order both to harmonise and to add value to existing regeneration initiatives; and

5. break stereotypical images of local people by supporting their entry and progression into the corporate sector and related local employment fields.

In 1997, Cityside set up a 'town management' scheme whose remit included events: Bengali New Year, Brick Lane and Curry Festivals. Businesses and residents from the area's diverse 'communities' were represented on the steering group and it was through this more broadly based forum that the Banglatown 'brand' was reintroduced, especially to promote the new festivals. The Evening Standard remained unimpressed: "Has no one ever told the council that 'Banglatown' began life as a White-yob insult?" (Barker, 1998), but in general the name became accepted as a neutral place-descriptor as Cityside's Director Andrew Bramidge commented

There was a lot of sensitivity about 'changing the name of the area', but it was never about renaming Spitalfields-a distinctive locality since medieval times. Rather, it was a marketing tool to get people to come and visit the area... A minority of people probably did want that-comparing it to Chinatown in the West End-but our view is that this was never an appropriate model. I think that it was quite an effective strategy because today you regularly get references to things happening in Banglatown (personal interview, 7 October 2002).

A key aim of Cityside's vision was "to achieve a quantum leap in the area's status as a visitor/cultural destination" (LB Tower Hamlets, 1996, p. 13). Brick Lane was also identified as a 'Developing Cultural Quarter' by the City Fringe Partnership (SRB-funded 1997-2002). It would thus be promoted to "tourists as well as employees and business visitors, helping to enhance the City's reputation as the premier European business loca- tion" (City Corporation, 1996, p. 17). Re-presenting Brick Lane as a cultural quarter would, however, require attention to the main 'gateways' or access points, together with better lighting to improve perceptions of personal safety. Cityside continued work initiated under City Challenge, including refurbishment of pedestrian subways, signage and ornamental gateway arches complemented by new, brighter street lamps, custom-designed to incorporate 'Asian' motifs. Cityside also administered grants for shop and restaurant owners to carry out frontage improvements, with design guidance and a wide range of business support. The vision recognised that the area would need at least one 'must see' attraction

A Cultural Heritage Centre will provide the area with its missing flagship attraction. It will foster a sense of pride amongst the local community and promote an image of London as an exciting and vibrant multicultural city ... The unique and beautiful listed building in Fashion Street, interconnected with the above, provides almost 100000 square feet and could provide a major 'bazaar/souk'. This will act as a key motor to the local economy, providing the missing 'ethnic' shopping experience (City Corporation, 1996, p. 14).

These two proposals were soundly based, but neither materialised during Cityside's fiveyear programme as the site owners had plans for more profitable uses. Grand Metropolitan had sold the brewery in 1992 to an entrepreneur who was previously a tenant on the site. Diversifying his core import-export business, the new landlord turned developer, refurbishing the buildings and gradually converting them to a lively mix of uses that did not include a cultural heritage centre. Ten years later these feature around 250 design studios, two bars/nightclubs, cafés, galleries, speciality retailers and a large exhibition centre. The same businessman also acquired the Moorish Market and applied for planning permission to convert it to studios and loftstyle apartments. Such developments have 
contributed greatly to the "vibrant visitor economy', but on emerging from the 'Designer's Block' exhibition at the former brewery, architectural journalist Jonathan Glancey expressed his anxieties for the future of 'shabby and wonderful' Brick Lane

'What worries me most is that whenever the design scene moves in on an old London street ... old businesses, shops where you can buy things for a song, restaurants where you can eat for a fiver vanish. Within a matter of months every second building is a café with raw concrete walls, difficult chairs, effete middle class youth trying to look hard and hard up, and menus offering holiday food at imaginative prices (Glancey, 1998, p. 16).

Notwithstanding the emphasis placed in the City Fringe 'Developing Cultural Quarters' programme (City Corporation, 1996, p. 17) on tourism that would help to raise the capital's international profile, Cityside's Director confirmed that their promotion has always been targeted at office workers, and "Londoners wanting to do something different in their own city" (personal interview, Bramidge, 7 October 2002). The Cityside Visitor Centre also responds to requests for literature from in-bound tour organisers, but there has been no proactive marketing to attract overseas or even domestic visitors. The influx of international tourists to the restaurant zone in recent years has therefore been something of a surprise. A notable example is the unexpected number of Japanese visitors to Brick Lane from 1999, a phenomenon that is attributed to guidebook and media coverage.

The success of Banglatown as a centre for ethnic cuisine has exceeded expectations, due mainly to the 'design scene' and other young White professionals from the nearby City. A survey of Brick Lane's catering sector carried out for Cityside noted that in 1989 there were only 8 cafés/restaurants in Brick Lane, with a few additions in the early 1990s. Between 1997 and 2002, this rose to 41 , of which 16 had opened in 2000-02, making Banglatown "home to the largest cluster of Bangladeshi/'Indian' restaurants anywhere in the UK" (Carey, 2002, p. 12). All the restaurants (as opposed to cafés) reported that their clientele was 'overwhelmingly White', with a clear majority (70 per cent) in the 25-34 age-group and predominantly male, (Carey, 2002, p. 4). The boom was facilitated by relaxed planning policies that allowed shops to be converted to restaurants. Furthermore, the central area of Brick Lane was designated a 'Restaurant Zone' where Class A3 uses (restaurants, cafés, hot food outlets, public houses and bars) would be 'favourably considered' (LB Tower Hamlets 1999).

By 2001, however, the discounting of menu prices and street canvassing by waiters indicated an excess supply of an undifferentiated product, which became more pronounced with the downturn after 11 September and the reluctance of some international tourists to visit a predominantly Muslim neighbourhood. The Council called a public meeting on the issue at which some restaurant owners argued that licences should be extended beyond midnight to boost trade. However, a number of White, middle-class residents of the Conservation Area to the west of Brick Lane argued that litter and anti-social behaviour by late-night customers was already a serious nuisance. Others argued that conversion to restaurants that commanded higher rents contributed to the loss of local shops. Unfortunately, a stormy exchange led to physical blows and required police attendance. LB Tower Hamlets then commissioned a survey of over 1500 residents from 'all communities', which confirmed widespread opposition to the proliferation of Class A3 uses and to any extension of opening hours (Agroni, 2001). At the time of writing, the Restaurant Zone remains in force, but LB Tower Hamlets (2002) has recently used its planning powers to protect the southern section of Brick Lane as a 'Local Shopping Parade', a policy that is fully supported by Cityside.

Although restaurants have undoubtedly brought job opportunities, the problems identified in recent years shed doubt on the 
wisdom of overreliance on this sector. Carey (2002) estimated that around 400 workers were employed in Brick Lane restaurants, of whom 96 per cent were of Bangladeshi origin, 92 per cent lived in the Borough and 99 per cent were men. A third of restaurant owners expressed concern over staff turnover and many felt that low pay and shifts made the work unattractive to younger Bengalis. Some said that it was risky to hire young local Bengali males who might be heroin or crack users, so they preferred to employ middle-aged men. Bengali women seemed extremely unwilling to work as waitresses, regarding restaurants as a largely male domain. Gender inequalities in the use of public space resulting from the visitor economy have also become apparent. LB Tower Hamlets Planning Officer Andrea Ritchie reported that in a recent focus group facilitated by the Borough

Older Bengali women stressed the point that they had to be escorted by their husbands and that they could not walk along Brick Lane at all because there are just too many men there, with all the visitors and [restaurant] staff. So, although it is their area, they are socially excluded from it (personal interview, 27 September 2002).

\section{Asian Fashions in Green Street, West Ham, LB Newham}

Green Street is also a busy retail and commercial thoroughfare within a multicultural district of inner London but, unlike Brick Lane which has come to depend on casual visitors from the nearby City and international tourists, Green Street is 6 miles from central London. Less than 30 years ago, the local population was predominantly White British and the street was best known for its associations with the nearby West Ham Football Club. During the 1970s, however, closure of the docks, along with several large manufacturing plant created high unemployment as well as out-migration. This caused a sharp downturn in trade for Green Street retailers. Over the same decade, the popu- lation became more ethnically mixed with immigration from New Commonwealth countries, including several hundred Asian refugees from Uganda. Amongst West Ham's new residents, there were some experienced entrepreneurs who acquired retail businesses. Initially, they concentrated mainly on selling food and fabrics at low prices, especially to the local Asian market. By 1990, the Green Street traders served a population estimated (LB Newham, 1994) to number 22 000, of whom 25 per cent were of Indian origin, 12 per cent Afro-Caribbean, 11 per cent Pakistani and 7 per cent Bangladeshi. Nevertheless, many retailers struggled to survive in the recession of the early 1990s, as local unemployment rose to 23 per cent (twice the London average).

Green Street thus continued to suffer economic and social disadvantage, and was identified by the local authority as one of five target areas for regeneration. The early 1990s were, nevertheless, something of a turningpoint; for one astute butcher (a former civil servant from Pakistan) decided to switch from selling halal meat to gold jewellery, and others began to realise the potential of selling high-value merchandise to the growing number of more affluent Asians in the London region. At the same time, LB Newham was revising its strategy for economic development. After some earlier difficulty in obtaining SRB funding for Green Street, in 1994 the Council led a successful bid for $£ 8.5$ million for a regeneration programme that brought forward proposals for business diversification and support, education and training, environmental improvements and community involvement. Its objectives (LB Newham, 1994) were to make Green Street a centre of regional significance for the largely Asian but multicultural community, providing a new dimension to east London's economy.

In accordance with this aim, over the next seven years (1994-2001) a range of "sensitively 'themed' environmental improvements celebrating the cultures represented in the area" (LB Newham, 1994, p. 2) were undertaken. These included shop-front improve- 
ments, renovation of the Queen Street market, a millennium pavement mural (involving local schools and community groups), improved street lighting, CCTV to help reduce street crime, as well as training, community development and business support. Whilst the management of the programme was the responsibility of the Stratford Development Partnership (the local regeneration agency), a Partnership for Green Street that included a wide range of local agencies, businesses and community groups, helped to determine local priorities for funding. Alongside this public funding, Asian traders were also investing in the area. Although it was difficult to assess the extent to which the rejuvenation of Green Street would have occurred without pump priming, the consultants evaluating performance of the programme after three years of SRB funding (EDAW 1997) reported that progress over the past decade had been 'phenomenal'. The investment made by the Asian business community had managed to resurrect a declining High Street and had created a new and dynamic retail centre.

EDAW (1997) emphasised the particular contribution of younger and more innovative Asian traders prepared to invest in window displays and store layout to improve the shopping experience. There was now a greater awareness of the need to develop a broader customer-base and to attract visitors from outside the local area. Nevertheless, with a high dependence of visitors on cars rather than public transport, it also stressed that traffic congestion and parking problems meant that there were limits to local capacity. In the late 1990s, the Partnership supported further growth through 'This is Green Street': a campaign to raise awareness of the area, featuring branded merchandising, as well as advertising in magazines and on ethnic minority radio. Familiarisation tours for the national press, travel operators and local teachers were also organised and, in 2000, a Quality Endorsement Scheme was introduced to identify retailers that provided highquality merchandise, exceptional customer service and a guarantee of satisfaction. A number of cultural events have been developed including 'Runga Rung': a winter celebration with live music and fireworks. Shopping in Green Street appears to have expanded and developed as a social experience for Asian families and trade remains buoyant. As Waldinger et al. suggest

The ethnic market becomes a place that ethnic shoppers frequent both for the goods they find available and for the role it plays in maintaining ethnic identity (Waldinger et al., 1990, p. 114).

As yet, no surveys have been carried out of the people who attend events such as Runga Rung to assess their ethnic origin or how far they have travelled. Nevertheless, interviews by the authors with officers and councillors suggest that Green Street is becoming well known amongst the dispersed Asian populations, not only within the London region, but throughout the UK and mainland Europe and North America (personal interview, Councillor H. Virdee, 4 October, 2002). It is therefore surprising that the 1994 application for SRB funding made no mention of the desirability or otherwise of developing a visitor economy. As the programme drew to a close, however, this was incorporated (Jacklin and Hughes, 1999; Hughes, 2000) and LB Newham (2001) subsequently announced a strategy to increase the number of out-Borough visitors and raise the profile of Green Street as a 'unique shopping centre'.

As their core market consists of customers of Asian origin, the traders in this area have had no reason to accommodate Western notions of the exotic East as some have done in North American and European Chinatowns and in 'Banglatown'. Furthermore, in its recent initiatives to promote the area as a visitor destination, LB Newham has been cautious about associating the 'Green Street brand' with any single community in an area that has such a rich mix of ethnicities and cultures. Leisure Services officer Ron Robinson commented that the Council was 
A bit reluctant to present it as a curiosity ... We were reluctant to go the whole hog such as Chinatown (personal interview, 30 October 2002).

Perhaps for similar reasons, LB Newham rejected proposals from consultants to set up Bradford-style 'curry trails'. In contrast to Brick Lane, the scene now presented to visitors features urban design that intentionally draws upon a broad range of cultural influences. For example, the lamp-post decorations and other street furniture have been designed to symbolise 'togetherness' and programme funding has also been used to commission a statue of the famous West Ham footballer Bobby Moore.

Although attracting an increasing number of people from outside the area, Green Street continues to function as a local shopping street. Fruit and vegetable stalls still stand alongside Asian fashion houses, but the upswing is inevitably causing rents to rise and, in future years, small shops catering for local needs may find it hard to survive in a location described by the Evening Standard (Jenkins, 2002) as the 'new Asian Bond Street'. It is uncertain how local residents will react to the worsening traffic and parking problems identified above, or to the Visitor Strategy proposals (LB Newham, 2001, p. 23) to "increase the quality, diversity and accessibility of eating places" and "further extend the trading day into the night". It is possible that Green Street may become more isolated from its local residential hinterland. In contrast to most of the Bengali residents in the area to the east of Brick Lane, however, the economic situation of many among the Asian communities around Green Street has improved. The development of a visitor economy is therefore balanced by increasing local demand for the type of luxury goods that are available in Green Street. The street is thus becoming a showcase for new Asian British designers offering clothes that draw on traditional Asian fashion but incorporate European influences, and which appeal to Asian British youth as well as White British and other ethic groups.

\section{Overview and Summary}

In the discourse of place marketing, Brick Lane and Green Street have been repositioned to take advantage of developments in London's globally oriented economy. An important element of this transformation has been diversification into luxury goods and services that are marketed to visitors from elsewhere in the capital and further afield. In both areas, the local state in partnership with commercial and not-for-profit organisations has initiated promotional campaigns that promote positive images of ethnic minorities as contributors to London as a 'world city'. Nevertheless, attempts to redefine and rename localities may well raise sensitive questions of identity and territory. The idea of promoting Brick Lane as Banglatown, first proposed by a consortium of Asian businessowners in the late 1980s, was contested by other ethnic groups and attracted hostile press coverage. Nearly a decade elapsed before the mainstream media accepted the Banglatown 'brand' as a theme to promote venues and events. Perhaps learning from this experience, LB Newham has eschewed the idea of associating Green Street with a single minority group; instead, the overarching theme of unity through diversity has been emphasised.

In both areas, ethnic minority entrepreneurs have capitalised on new market opportunities and the commercial success of leading individuals has encouraged others to follow. Where diversification involves land use change, it is highly likely that property owners and traders will lobby for relaxation of development control policies. In the case of Brick Lane, a recently adopted Unitary Development Plan was revised to allow conversion of older manufacturing and retail premises to restaurants, cafés and bars. Nevertheless, part of the street was later reinstated as a neighbourhood shopping parade to try and retain the few remaining local convenience stores. And, in both areas, pressures to extend licensed opening hours into the early morning have so far been resisted. Although minority businesses have been the 
prime agents of change, an emerging visitor economy is unlikely to succeed without considerable infrastructure investment, especially to improve access and the public realm. In the case of Brick Lane, the local state with support from central government funded 'gateways' linking the main thoroughfare with public transport and offices in the nearby City of London, including measures to improve personal security after dark. In Green Street, greater dependence on private cars required traffic management and greater parking capacity. Discretionary grants have also been made available to encourage refurbishment of street façades and, in Green Street, an endorsement scheme was used to promote outstanding quality in goods and services offered.

In principle then, the local state, usually in partnership with other stakeholders, may create a framework of regulations and incentives to guide change. In both areas, the five-year SRB programmes were very successful in terms of the measurable outcomes that were set in the mid 1990s when their funding was awarded. The number of business start-ups and level of employment growth have been impressive; increases in property values and investment in the built environment have been significant. The longitudinal case studies suggest, however, that the development of an emerging visitor economy and its consequences for the local population, income, employment and the physical environment are hard to predict. In Brick Lane, the plans to develop a 'cultural quarter' based around a flagship multicultural heritage attraction were abandoned as the site owner converted the buildings to accommodate activities that include barrestaurants, night-clubs and an exhibition centre: forms of leisure consumption that differ considerably from those envisaged at the outset. The quality job opportunities generated by this sector are now being questioned and tensions have emerged over its effects, including conflicts over the use of public space. In Green Street, the local partnership has been highly supportive of the fashion jewellery and clothing outlets. From the early 1990s, these attracted an increasing volume of shoppers from a wide catchment area, but it was not until the end of the decade that the need for a visitor strategy was formally acknowledged. Accommodation of the Urban Renaissance agenda of the late 1990s and the policy turn that embraces environmental quality, social inclusion and community benefit thus presents some challenging issues and problems to resolve at the local level.

\section{Conclusion}

The case studies discussed above highlight the need to understand the processes through which multicultural districts are selected and redefined as destinations for leisure and tourism consumption. As yet, the changing pattern of demand for the goods and services that they offer and the response of minority entrepreneurs have not been the subject of extensive empirical research. Traditionally, commercial thoroughfares of migrant enclaves in large cities have functioned as retail centres catering for the requirements of ethnic minorities, as well as social and economic hubs for dispersed members of expatriate communities. These functions continue, but their global linkages make them more fluid and dynamic ethnoscapes: places associated with immigrants, exiles, guestworkers and other mobile groups (Appadurai, 1997). Over the past two decades, dramatic reductions in air fares have increased opportunities for family and social ties as well as business contacts to be maintained through more frequent travel to and from distant homelands. Overseas Chinese in New York and Latin Americans in Los Angeles are notable examples (Urry, 2002), as are the migrants from India, Pakistan and Bangladesh in the areas of east London described above.

The same thoroughfares may also attract members of the majority culture, perhaps mainstream international tourists. The demand is highly diverse: quests for knowledge and understanding of other cultures co-exist 
with more mundane quests for take-away food and drink. Some visitors are attracted by colourful street markets, festivals, world music and other performance art; others by bars, clubs and late-night entertainment in quasi-exotic settings. A positive interpretation is that, with appropriate business advice, entrepreneurs from ethnic and cultural minorities will prosper by developing niches in this heterogeneous market. With basic training in service-oriented skills, inner-city residents will find employment in a growing sector that compensates for decline in older trades. Low-skilled and low-paid work should be regarded as a temporary phenomenon, as more educated, second-generation migrants will gain access to professional work. With improving business confidence, new uses for old buildings will fund the restoration and conservation of neglected urban landscapes. Partnerships between public, private and not-for-profit organisations will provide the necessary commitment and resources to upgrade the public realm to the benefit of local users as well as the visitors who are being encouraged to enter inner-city streets.

A less optimistic prognosis is that, without effective planning and management that is accountable to the local electorate, 'success'-in terms of physical and economic regeneration-may create serious difficulties for the very communities that should gain most from the programme. At the micro level, with an increasing number of visitors, spontaneous interethnic and intercultural encounters will no longer occur. The one-way traffic and attention of onlookers will become intrusive, disturbing the rhythm of people's everyday lives, reducing rather than improving the quality of their local environment. At the macro level, the unleashing of market forces may well lead to an inequitable distribution of costs and benefits. The leisure and tourism sector may do little to improve employment mobility and the prospect of better-paid work. Where planning controls are weak, or where they have deliberately been relaxed, changing land use will raise property values. This will clearly benefit land owners that may include ethnic minority entrepreneurs. However, such commercial gentrification is likely to drive out small businesses, especially those serving local needs such as food shops. Low-income residents may also be displaced unless privatesector rents are controlled and/or suitable social housing is available. Ironically, the sign-posting of difference will produce an anodyne and relatively homogeneous culture of consumption, disconnected from the social life of the local population. In time, this will create an isolated, tourism-oriented enclave; a sharp and cruel contrast to the poverty of adjacent inner-city areas that are less appealing to the gaze of visitors.

Despite these concerns over the longerterm sustainability of this market for ethnic goods and services in an 'exotic' urban setting, a number of inner-city authorities in the UK and elsewhere in Europe are actively encouraging the processes that will establish such areas on the urban tourist map. The public policy discourse of regeneration programmes such as Cityside and City Fringe SRB programmes, with their emphasis on identification and realisation of opportunities to overcome the isolation of place and marginalisation of migrant communities, appear fully in tune with Porter's (1995) thesis on the competitive advantage of the inner city. The locational advantages of proximity to markets must be fully exploited, but a visitor economy is unusual in that the consumer must necessarily go to the product. In this context, the place is conceptualised as the 'product' to be repositioned. Differentiation from competing place-brands-in this case, through distinctive ethnic or cultural associations - must be highlighted and promoted to target audiences, following Kotler et al.'s (1993) advocacy of strategic image management to reposition destinations that may include small areas, such as districts within cities.

According to this North American model of regeneration, dependence on welfare and other state support can be reduced if entrepreneurial talent, especially that of ethnic minority businesses, can be unlocked and 
connected more effectively with the 21 stcentury global economy. Regeneration programmes that adopt the 'Chinatown' model to achieve these aims, define and mark out commercial and cultural spaces associated with one minority group as a destination for visitors. As with the internal space of restaurants, exotic motifs are accentuated within the bounded enclave to create an ambience conducive to leisure and tourism consumption. This 'monocultural' approach helps to create a strong unifying theme that is easy to communicate to prospective place-consumers, but the imagery projected to visitors may reconfirm rather than challenge stereotypes. Furthermore, its territorialisation of the public realm may alienate those who perceive little personal benefit, marginalising if not excluding other minorities. The example of Green Street, nevertheless, provides a more inclusive model that is oriented to diverse markets, including wealthier Asian shoppers from a national and even international catchment area. Its deliberate use of multicultural imagery may be less problematic and may gain support from a wider range of local as well as external stakeholders.

The development of visitor economies in disadvantaged, multicultural districts pays tribute to the active role of migrant entrepreneurs in the regeneration of European cities. The process may help raise 'local pride' in areas where low self-esteem has, for many years, been reinforced by the negative perceptions of outsiders. Decoupled from the established European systems of urban governance and land use planning, it may, however, take on a momentum of its own. As well as ethnic and cultural difference, there is an inherent imbalance of power, wealth and mobility between the visitors and the visited. Not only the exoticised urban landscapes, but the 'host' population itself becomes the object of curiosity. Urban authorities and regeneration agencies can offer a clear vision of desirable outcomes, but they can seldom predict with any certainty how these will impact on the everyday lives of local residents and small businesses. As Atkinson (2003) suggests, the process is inherently divisive, as it requires cities, local authorities and communities to demonstrate that they have internalised the particular discourses of competition promoted by neo-liberal ideology. Unwillingness to do so carries with it the risk of being identified as a 'failing' city or locality. Without a balanced and open dialogue between municipalities and the diverse communities who live and work in inner-city areas about the development of urban tourism, the process may exacerbate rather than defuse tensions in areas that, in many cases, have long and violent histories of intolerance towards minority groups.

\section{References}

Agroni (2001) Brick Lane Restaurant Zone Consultation Report. November, Agroni, London.

Aitchison, C., MacLeod, N. and Shaw, S. (2002) Leisure and Tourism Landscapes: Social and Cultural Geographies. London: Routledge.

ANDERSON, K. (1995) Vancouver's Chinatown: Racial Discourse in Canada, 1875-1980. Montreal: McGill-Queen's University Press.

ApPadurai, A. (1997) Modernity at Large: Cultural Aspects of Globalisation. Minneapolis, MN: University of Minnesota Press.

Ashworth, G. (1996) Realisable potential but hidden problems: a heritage tale from five central European cities, in: J. Purchla (Ed.) The Historical Metropolis: A Hidden Potential, pp. 151-155. Cracow: International Culture Centre.

Ashworth, G. and Voogt, H. (1994) Marketing and place promotion in: J. GOLD and S. WARD (Eds) Place Promotion: The Use of Publicity and Marketing to Sell Towns and Regions, pp. 39-52. Chichester: Wiley.

AtKinson, R. (2003) Addressing urban social exclusion through community involvement in urban regeneration, in: R. IMRIE, and M. RACO (Eds) Urban Renaissance? New Labour, Community and Urban Policy, pp. 109-119. Bristol: The Policy Press.

BARKER, P. (1998) London is no place for this ghetto mentality, Evening Standard, 3 August, p. 11 .

BARTH, F. (1994) Enduring and emerging issues in the analysis of ethnicity, in: H. VERMEULEN and C. Govers (Eds) The Anthropology of Ethnicity: 'Beyond Ethnic Groups and Boundaries', pp. 20-31. Amsterdam: Het Spinhuis. 
BiLes, A. (2001) A day-trip to the urban jungle, Regeneration and Renewal, 17August, pp. 1415.

Bogdanowski J. (1985) Problemy metodologiczne rewaloryzacji urbanistyczno-krajobrazowej miasta zabytkowego na przykladzie Kazimierza Krakowskiego. Warszawa: PKZ.

Burgess, J. (1985) News from nowhere: the press, the riots and the myth of the inner city, in: J. BuRGESS and J. GolD (Eds) Geography, The Media and Popular Culture, pp. 192-228. London: Croom Helm.

BuRGHe, P. L. VAN DEN (1994) The Quest for the Other: Ethnic Tourism in San Cristobal. Mexico, Seattle, WA: University of Washington Press.

Butler, T. (1996) People like us: the gentrification of Hackney in the 1980s, in: T. BUTLER and M. RUSTIN (Eds) Rising in the East. The Regeneration of East London, pp. 81-107. London: Lawrence \& Wishart.

CABINET Office (1988) Action for Cities. London: HMSO.

CAREY, S. (2002) Brick Lane, Banglatown: a study of the catering sector. Final report, prepared for Ethnic Minority Enterprise Project and Cityside Regeneration, Research Works Ltd, Hendon.

City CoRPORATION (1996) Revitalising the city fringe: inner city action with a world city focus. London: City Corporation.

Colenutt, B. and Cutten, A. (1994) Community empowerment in vogue or in vain?, Local Economy, 9, pp. 233-245.

Community Development Group (1989) Planning Our Future. London: CDG.

Cullingworth, B. (2002) Town and Country Planning in the UK, 13th edn. London: Routledge.

DETR (DEPARTMENT OF THE ENVIRONMENT, Transport AND THE REgIONS) (1998) Single Regeneration Budget Bidding Guidance: A Guide for Partnerships (Round 5). London: The Stationery Office.

DudA, E. (1991) Krakowskie Judaica. Warszawa: PTTK Kraj.

EDAW (1997) Green Street Partnership Interim Study, Final Report. London: EDAW.

EDwARDS, C. (2003) Disability and the discourses of the Single Regeneration Budget, in: R. IMRIE and M. RACO (Eds) Urban Renaissance? New Labour, Community and Urban Policy, pp. 163-180. Bristol: The Policy Press.

ERDENTUG, A. and Colombijn, F. (2002) Urban Ethnic Encounters: The Spatial Consequences. London: Routledge.

Fainstein, S. (2001) The City Builders: Property Development in New York and London 1980 2000, 2nd edn. Lawrence, KS: University Press of Kansas.
Featherstone, M. (1991) Consumer Culture and Postmodernism. London: Sage.

GlanceY, J. (1998) Changing places, The Guardian, Spaces supplement, 10 September, p. 16.

HALL, D. (2002) Branding and national identity: the case of central and eastern Europe, in: N. Morgan, A. Pritchard and R. Pride (Eds) Destination Branding: Creating the Unique Destination Proposition, pp. 87-105. Oxford: Butterworth-Heinemann.

Henry, N., McEwan, C. and Pollard, J. S. (2002) Globalisation from below: Birmingham-postcolonial workshop of the world?, Area, 34(2), pp. 117-127.

Нiтснсоск, M. (1999) Tourism and ethnicity: situational perspectives, International Journal of Tourism Research, 1, pp. 17-32.

Hughes, G. (2000) Tourism promotion, in: Green Street Partnership Project Reports 1999/2000, LB Newham.

HumphreYs, R. (2002) The Rough Guide to London. London: Rough Guides, distributed by Penguin.

JACKLIN, L. and Hughes, G. (1999) Project report: tourism promotion, in: Green Street Partnership Project Reports 1998/9, LB Newham.

JACOBS, J. M. (1996) Edge of Empire: Postcolonialism and the City. London: Routledge.

Jenkins, S. (2002) Big business in Little Asia, Evening Standard, 24 January.

JudD, D. (1999) Constructing the tourist bubble, in: D. JudD and S. FAInsteIn (Eds) The Tourist City, pp. 35-53. New Haven, CT: Yale University Press.

KIN (2000) Raport z Seminarium, Perpektywy rozwoju Kazimierza, pp. 59-61. Cracow: KIN.

Kotler, P., Haider, D. and ReIN, I. (1993) Marketing Places: Attracting Investment, Industry, and Tourism to Cities, States and Nations. New York: The Free Press.

LANDRY, C. and BiAnCHINI, F. (1995) The Creative City. London: Demos.

LB Newham (1994) Green Street-A Regional Role in Tomorrow's East London. LB Newham.

LB NEWHAM (2001) A Visitor Strategy for Newham 2001-2006. LB Newham.

LB TOWer Hamlets (1996) Eastside Challenge Fund Submission. LB Tower Hamlets.

LB TOWER HAMLETS (1999) Brick Lane Retail and Restaurant Policy Review, 1 March. LB Tower Hamlets.

LB TOWER HAMLETs (2002) Brick Lane Retail and Restaurant Policy Review, 9 January. LB Tower Hamlets.

LuTZ, J. and Ryan, C. (1997) Impacts of inner city tourism projects; the case of the International Convention Centre, Birmingham, UK, in: P. Murphy (Ed.) Quality Management in 
Urban Tourism, pp. 41-53. Chichester: John Wiley and Sons.

Maitland, R. (2003) Cultural tourism and the development of new tourism areas in London. Unpublished paper presented at ATLAS Cultural Tourism Research Group Expert Meeting, Cultural Tourism: Globalising the Local-Localising the Global, Barcelona, OctoberNovember.

Newman, P. and Thornley, A. (1996) Urban Planning in Europe: International Competition, National Systems and Planning Projects. London: Routledge.

North, P. (2003) Communities at the heart? Community action and urban policy in the UK, in: R. IMRIE and M. RACO (Eds) Urban Renaissance? New Labour, Community and Urban Policy, pp. 121-138. Bristol: The Policy Press.

Orbasli, A. (2000) Tourists in Historic Towns: Urban Conservation and Heritage Management. London: Spon.

PADDISON, R. (1993) City marketing, image reconstruction and urban regeneration, Urban Studies, 30(2), pp. 339-350.

PASZUCHA, M. (1995) Managing places-Krakow. Paper presented to the Historic Cities and Sustainable Tourism-The Protection and Promotion of the World's Heritage, ICOMOS UK Conference, Bath, October.

PorTer, M. (1990) The Competitive Advantage of Nations. New York: The Free Press.

PORTER, M. (1995) The competitive advantage of the inner city, Harvard Business Review, May/ June, pp. 55-71.

PotTs, G. (2002) Competitiveness and the social fabric: links and tensions in cities, in: I. BEGG (Ed.) Urban Competitiveness: Policies for Dynamic Cities, pp. 50-80. Bristol: The Policy Press.

SAID, E. (1978) Orientalism. London: Routledge and Kegan Paul.

Schofield, P. (1996) Cinematic images of a city: alternative heritage tourism in Manchester, Tourism Management, 17(5), pp. 333-340.

Shaw, S. (2004) The Canadian 'world city' and sustainable downtown revitalisation: messages from Montreal 1962-2002, British Journal of Canadian Studies (in press).

SHAw, S. and MACLEOD, N. (2000) Creativity and conflict: cultural tourism in London's city fringe, Tourism, Culture and Communication, 2(3), pp. 165-175.
Smith, V. L. (Ed.) (1989) Hosts and Guess: The Anthropology of Tourism. Philadelphia, PA: University of Pennsylvania Press.

TAYLOR, I. (2000) European ethnoscapes and urban redevelopment: the return of Little Italy in 21st century Manchester, City, 4(1), pp. 27-42.

TIME Out (London) (2002) Eat your way around the world, July, pp. 17-24.

Tunbridge, J. and Ashworth, G. (1996) Dissonant Heritage: The Management of The past as a Resource in Conflict. Chichester: John Wiley and Sons.

URRY, J. (1990) The Tourist Gaze: Leisure and Travel in Contemporary Societies. London: Sage.

URRY, J. (2002) Small worlds and large distances. Paper presented to ESRC Mobile Network seminar on 'Social Impacts of the UK Air Transport Industry', Imperial College London, September.

Waldinger, R., Mcevoy, D. and Aldrich, H. (1990) Spatial dimensions of opportunity structures, in: R. WALDINGeR, H. AldRICH and R. WARD (Eds) Ethnic Entrepreneurs: Immigrant Businesses in Industrial Societies, pp. 106-130. London: Sage.

Ward, S. (1998) Selling Places: The Marketing and Selling of Towns and Cities 1850-2000. London: Spon.

Warde, A. (1995) Consumption, Food and Taste: Cultural Antinomies and Commodity Culture. London: Sage.

Williams, G. (2003) The Enterprising City Centre: Manchester's Development Challenge. London: Spon.

WoODWARD, R. (1993) One place, two stories: the two interpretations of Spitalfields in the debate over its redevelopment, in: G. KEARNS and C. PHILO (Eds) Selling Places: The City as Cultural Capital Past and Present, pp. 253-266. Oxford: Pergamon Press.

Zelinski, W. (1985) The roving palate: North America's ethnic restaurant cuisines, Geoforum, 16(1), pp. 51-71.

Zukin, S. (1991) Landscapes of Power: From Detroit to Disney World. Berkley, CA: University of California Press.

ZuKIN, S. (1999) Urban lifestyles: diversity and standardisation in spaces of consumption, $U r$ ban Studies, 35(5/6), pp. 825-839. 